\title{
Developing Learner Autonomy Through Project Work in an ESP Class
}

\section{Desarrollo de la autonomía del aprendiz a través del trabajo por proyectos en una clase de inglés con fines específicos*}

\section{Martha Isabel Díaz Ramírez}

marthadiazramirez@hotmail.com

Universidad de Cundinamarca, Colombia

This article presents the findings of an action research study on developing learner autonomy through project work in an English for Specific Purposes class. The study was conducted at a Colombian regional and public university with environmental engineering undergraduates. The instruments for data collection were field notes, semi-structured interviews, questionnaires, students' artifacts, and video recordings. The results revealed that learner autonomy could be developed by means of cooperative work in order to achieve common interests and support each other. Students also displayed self-regulation in regard to facing failures through learning strategies; furthermore, this study showed how intrinsic motivation implies the desire for accomplishment and knowledge to fulfill a learning goal.

Key words: Autonomy, cooperative work, motivation, project work, self-regulation

Este artículo presenta los resultados de una investigación-acción sobre el desarrollo de la autonomía del aprendiz a través del trabajo por proyectos en una clase de inglés con fines específicos. La investigación se realizó en una universidad regional y pública de Colombia con estudiantes de ingeniería ambiental. Se utilizaron diarios de campo, entrevistas semi-estructuradas, cuestionarios, la producción de los estudiantes y la grabación en vídeo para recolectar los datos. Los resultados revelaron que la autonomía del aprendiz se podría desarrollar a través del trabajo cooperativo con el fin de lograr intereses comunes y el apoyo mutuo. Los estudiantes también demostraron autorregulación para enfrentar las falencias mediante estrategias de aprendizaje y este estudio mostró cómo la motivación intrínseca implica el deseo de cumplimiento y conocimiento para lograr un objetivo de aprendizaje.

Palabras clave: autonomía, autorregulación, motivación, trabajo cooperativo, trabajo por proyectos

* Received: January 14, 2014. Accepted: August 18, 2014.

How to cite this article (APA $6^{\text {th }}$ ed.):

Díaz Ramírez, M. I. (2014). Developing learner autonomy through project work in an ESP class. HOW, $A$ Colombian Journal for Teachers of English, 21(2), 54-73. 


\section{Introduction}

The role of teachers is not meaningful for transmitting knowledge, but for creating proper conditions for the construction of knowledge. In addition, the Colombian education system seeks to promote proficient learners in language skills as well as to enhance their cognitive and intercultural development, but suitable conditions to meet this requirement do not exist in our public education system. That is why there is a high risk that formal education may affect learners' autonomy (making their own learning decisions) due to the fact that students tend to be passive, that is, they just do what they are required to do without judging what teachers implement in classes.

This paper describes a project implemented in a Colombian public university with undergraduate students in a class of English for Specific Purposes (ESP). The idea behind the project was to foster learners' autonomy through the application of cooperative work, allowing each student to be responsible for specific tasks and, in general, to take charge of her/his own learning process. In the following section there is a brief overview of similar studies developed around project work and an explanation of the key concepts under discussion: autonomy (Jiménez Raya, Lamb, \& Vieira, 2007) and project work with their phases (Stoller, 2002) and their role in creating authentic conditions and activities that encourage meaningful learning. Then, a description of the context and method of the study will be offered followed by the analysis, results, and conclusions.

\section{Literature Review}

Legutke (2005) shared three research projects in German classrooms, but for this study it is essential to mention only one called "English just around the corner: The classroom as a place of encounter." This study was conducted with a team using 11 and 12-year-old students who did an interview project at an airport. These students interviewed different people of different nationalities and chose the best interviews to type their transcriptions and construct texts using computers while others created a wall chart about a portrait of an interesting traveler at the airport. Students then shared what they had done with their parents (creating action zones to present their productions). The main contribution of this study was to analyze how it was possible for learners to make decisions to achieve common interests such as writing articles and designing their own magazines to be launched at the end of the project.

Another study by Petersen (2004) was carried out to reflect on the use of project work and the importance of students' needs. Petersen analyzed teachers' and students' perspectives and the use of project-based learning (PBL) at two ESL schools with diverse student populations. Petersen stated that "teachers must first consider the backgrounds and needs of the students 
in order to have lessons and activities which suit them and their daily language learning needs" (p. 116).

Another study concentrated on shifting teaching from teacher-centered instruction to student-centered instruction and applying action research "to validate the project's effectiveness by measuring both the performance of teachers and children" (Ho, 2003, p. 43). This study is useful to get a better understanding of how feasible it is to have a student-centered classroom in which learners make decisions and delegate responsibilities among the members of a group.

Finally, Robayo Luna and Hernandez Ortiz (2013) analyzed what collaborative writing through project work told us about students' academic writing development at a private university in Bogotá. The main contribution of this study emerged from the need to apply a pedagogical intervention in order to support students with their low proficiency level in contrast to their wishes about learning. Students were beginners, but they decided to design and write their own magazines creating editorial groups to support each other.

\section{Project Work}

The main aim of project-based learning is "to provide opportunities for language learners to receive comprehensible input and produce comprehensible output" (Beckett \& Miller, 2006, p. 4). These opportunities are given in a meaningful context in which the learner is motivated to perceive the language not just as an academic subject, but as an instrument for expression and comprehension in a foreign language context. Beckett and Miller (2006) state that the goal of project-based learning is to provide learners with chances to recycle known language and skills in natural contexts. In fact, project work fosters active roles for students in which the learners can engage in authentic and interesting tasks to achieve a common goal by means of collaborative work and the teacher provides them with opportunities to improve language skills for communicating successfully.

These individual and cooperative tasks highlight the main features of project-based instruction, which places emphasis on the learner and how the learner exercises autonomy. There are several definitions regarding project work and it is relevant to distinguish some of them. It is suggested that a "project is the development of an experience centered on the student and his environment, that it is a creative and enriching experience on the student's interest" (Jiménez Raya, 1994, p. 52 [trans.]). Secondly, project work "is a versatile vehicle for fully integrated language and content learning" (Stoller, 1997, p. 3). Students are invited to live a meaningful experience that goes beyond the syllabus and classroom walls. This way, learners and teacher negotiate how they will implement a project in their own context based on their needs. Regarding the previous definitions, project work can be understood as a successful way to provide learners with opportunities to create their own planning in the classroom. It 
focuses on the learner, promotes the development of intrinsic motivation and positive attitudes towards learning; it increases student responsibility, fosters participation when making decisions concerning projects, facilitates the gradual acquisition of autonomy and the use of the language, and promotes interdisciplinary and cooperative work.

Phases in project work. Stoller (2002) suggested some steps to carry out a project (see Appendix 1). These stages go from the first step to reach an agreement about a topic until evaluating the project. It is essential to mention that "when projects are structured to engage students actively in early project planning (even if student contributions are small), students gradually develop a sense of ownership and pride in the project" (Stoller, 2006, p. 27). It means that when learners are provided with opportunities throughout a project, they develop a sense of commitment and involvement which promotes their autonomy. It goes without saying that defining the project topic is the first phase and one of the most meaningful decisions that students make. It has a positive impact on student attitude and helps learners feel comfortable while working for a long period of time. It is relevant to "ensure that the topic is challenging but not too difficult, allowing for imaginative and creative thinking" (Guo, 2006, p. 146). An eye-catching topic will determine the students' motivation to carry it out. If learners do not have a deep and genuine reason for learning, they will not act autonomously.

In the following section, the concept of autonomy will be given because our students were expected to become critical thinkers capable of reflection and self-evaluation, instead of being dependent on others' directions.

\section{Defining Autonomy}

It is necessary to point out the difficulty in defining the concept of autonomy. It is related to freedom and self-government, although being autonomous also implies responsibility for the individual's performance. During the process of learning and teaching, responsibility involves both the learner's and teacher's own engagement when promoting independence. Autonomy is defined as "the competence to develop as a self-determined, socially responsible, and critically aware participant in (and beyond) educational environments, within

a vision of education as (inter)personal empowerment and social transformation" (Jiménez Raya et al., 2007, p. 1).

This definition, according to the previous authors, has a democratic point of view because it has holistic outcomes such as developing social skills to be placed into use in their communities and students are given possibilities to exercise their autonomy in any context. It means that autonomy implies taking one's own initiative, in this case, exercising control over the learning process. Learner autonomy aims at encouraging the gradual development of self-government with progressively greater responsibility being taken on by learners not only 
for increasing their level of proficiency, but also for enhancing their abilities, styles, preferences, and participation in the communities.

\section{Context of the Study}

This project was carried out in a public university located in Facatativá, Cundinamarca (Colombia). This university looks forward to having new autonomous, leading, and professional citizens to develop their flower industry region. What is more, Facatativá has a high potential of agricultural and industrial work to be explored and developed by future environmental engineers. As a result, undergraduate students of environmental engineering are required to be bilingual to support the process of internationalization in growing industries. However, students in general do not have the minimum English level required by the university when seeking admission and they are not interested in learning English.

As a starting point, the participants of this study took a diagnostic test but no one passed it: On a grading scale of $0-5.0$, two students got less than 1.0 , eight students were between 1.1 and 2.1, and six students got grades between 2.1 and 3; none of them could get more than 3.0 and on the written part-which only $25 \%$ of the students attempted to answer-some students wrote down general phrases, for instance: "OK, I go to your house at 3:00 pm," "I like eat potatoes and soda" [sic]. According to them, they did not have the appropriate knowledge for writing and they felt very discouraged when they saw their diagnostic test scores. In addition to the diagnostic test, students were asked to complete a questionnaire about learners' autonomy. Some results showed that none of them makes conscious decisions in order to establish learning goals.

At this university, students do not have any specific book for their English Class Level 1 - the class in which the project was implemented-so each professor takes into account the Common Reference Levels put forth by the Common European Framework to design each syllabus and prepare their classes; in this case, level A1: Basic User. The group consisted of ten boys and six girls ranging in age from 16 to 22 . Most of them worked in the afternoons or on weekends to pay expenses. These students belonged to a low economical stratum whose parents earned minimum wages. For this reason, the university offers students special services such as scholarships, free lunch and dinner, tokens for transportation, and other benefits.

This study was based on Stoller (2002) since, according to this author, the emphasis of project work is on the student-centered classroom and the integration of skills in a real context. The selection of project-based learning emerged from thinking about how to maximize students' participation in learning in which the teacher's role is to act as a facilitator in the communicative process. 
During the first steps of project work, students were asked to choose a topic they liked to work on during the semester. They decided to create a magazine according to their preferences about environmental issues. While they were working on their magazines, they were able to involve themselves in activities in which they could be creative and work independently because they assigned tasks to each member of the group in order to ensure a successful completion. Furthermore, this study was carried out over an academic semester taking into account ten stages in project work (see Appendix 1) in which field notes, semi-structured interviews, questionnaires, students' artifacts, and video recordings were used to collect data. This study focused on promoting the learners' L2 autonomy through project work, bearing in mind students' specific needs and interests as well as the social context in their community. That is to say, the implementation of this study allowed students to be directly responsible for their own learning by developing autonomy when learning English, while, at the same time, involving them in real-life situations. The following research question was designed:

What is the role of project work on learner autonomy in an ESP class?

\section{Method}

A descriptive and qualitative case study was carried out to answer the research question. A case study, according to Wallace (1998), is "a systematic investigation of an individual case, whether that refers to one teacher, one learner, one group, or class, or whatever" (p. 47). Thus, a case study aims at understanding a particular case and its complexity.

A qualitative research project is defined as "any kind of research that produces findings not arrived at by means of statistical procedures or other means of quantification" (Corbin \& Strauss, 1990, p. 17). On the other hand, descriptive studies offer a rich and detailed account of events and interactions, which favors an in-depth understanding of realities and contexts.

\section{Instruments for Data Collection}

Instruments for data collection depend on the type of research. In this case, a qualitative research approach "involves the studied use and collection of a variety of empirical materials - case study, personal experience, introspection, life story, interviews, artifacts, cultural texts and productions, observational, historical, and visual texts- that describe routine and problematic moments and meanings in individuals' lives" (Duff, 2008, p. 27). It means that a qualitative research can use students' artifacts regarding their English process in order to have detailed data. For this reason, field notes, conferences, students' journals, and questionnaires were selected to analyze learner autonomy in each group. 
Students' artifacts. This study collected students' written artifacts such as biographies, journals, and editorials. This instrument played an important part in getting data about students' autonomy due to the fact that students' production was tangible evidence of the students' responses to each project work phase.

Field notes. Field notes were descriptions and comments from the observer about students' attitudes, opinions, and reactions regarding their learning during the development of the classes. Each class session, a field note form was filled out because it served as a memory aid to register important events.

Semi-structured interviews. Semi-structured interviews are interviews with open questions to find out — with a degree of freedom — data to develop the questionnaire face to face. They were applied at the middle and end of the study to clarify the researcher's questions.

Students' journals. Students kept a journal for expressing opinions and beliefs about learning English since this type information was important to verify how learner autonomy was working in each group. Students wrote about what they had learned and done in class, the difficulties they encountered and proposals to improve their learning. This type of instrument was useful to identify students' points of view about their own learning process during the study's development.

Video recordings. Video recordings provided relevant information that was not feasible with other instruments. For example, non-verbal communication showed students' attitudes when working in groups during the presentation of the magazines.

Questionnaires. Questionnaires were applied at the beginning and at the end of the semester. The questionnaires aimed to obtain information about learners' opinions regarding motivation, responsibility, learner autonomy, cooperative work, and learner strategies.

In the following section, the data gathered from the instruments were analyzed in order to verify the role of project work on learner autonomy.

\section{Data Analysis}

Learners were characterized by their lack of autonomy when they arrived at this level of English as shown in Excerpt 1:

\section{Excerpt $1^{1}$}

S1: ${ }^{2}$ Teacher, we don’t have much time to practice English.

1 This excerpt has been translated from its original language, Spanish.

2 Codes: $\mathrm{S}=$ Student, $\mathrm{Q}=$ Questionnaire, $\mathrm{SJ}=$ Student's Journal, FN=Field Notes, $\mathrm{SS}=$ Session 
S3: My former English teacher gave us guides to complete and we just followed her suggestions.

S4: On weekends, I work.

S7: Most of us live on farms and we only learned verbs.

S8: I don't like English much. At school, we just used to fill in forms.

S9: Teacher, we worked workshops grammar.

S10: Teacher we worked in high school what our miss said.

Since they did not usually take risks, they were not conscious of their active role in learning, especially in terms of responsibility. They simply waited to receive worksheets with grammar structures to be completed because most of our students were taught to be dependent as a result of teacher-centered schools where the Grammar-Translation Method was mostly used.

The researcher identified three main categories. The first category was called Cooperative Work Influence on Autonomy, which was evident when students created teams and developed their magazines; this category was explained in one subcategory. Students were able to work cooperatively because they shared a common interest: to create their environmental magazine. The second category was Self-Regulation, which is a feature of learner autonomy and it was shown when learners provided evidence of expressing control of the use of language. The last category was named Intrinsic Motivation, that is, students showing their own interest when learning. After having given a general idea about the categories, I think it is important to describe and analyze each of them in depth in the following lines.

\section{Results}

\section{Cooperative Work Influence on Autonomy}

Students decided to work in teams in order to reach a common goal and they were able to develop their own autonomy after being explained what project work was. In the second session, they decided to work on environmental issues by voting.

Making decisions together. The first step that students took was to organize teams in order to create their magazines at their own discretion. Afterwards, they chose the name of their magazines together. For example, three students called their magazine "Environment Culture in Facatativá" (see Appendix 2) and decided upon each member's duties, purpose, audience, materials, activities, and schedule. Hyland (2005) highlighted some characteristics of writer positioning called self-mentions, which "refers to the use of first person pronouns and possessive adjectives to present propositional, affective, and interpersonal information" (p. 81). Students expressed how they created their magazine as a group. From the beginning 
of the application of the project, learners described the classroom and project events using the first person plural pronoun "we" or the possessive adjective "our". Students showed commitment to work in groups as shown in Figure 1, where they evaluated their work. Students decided together how they were going to design and to share their magazines in the classroom.

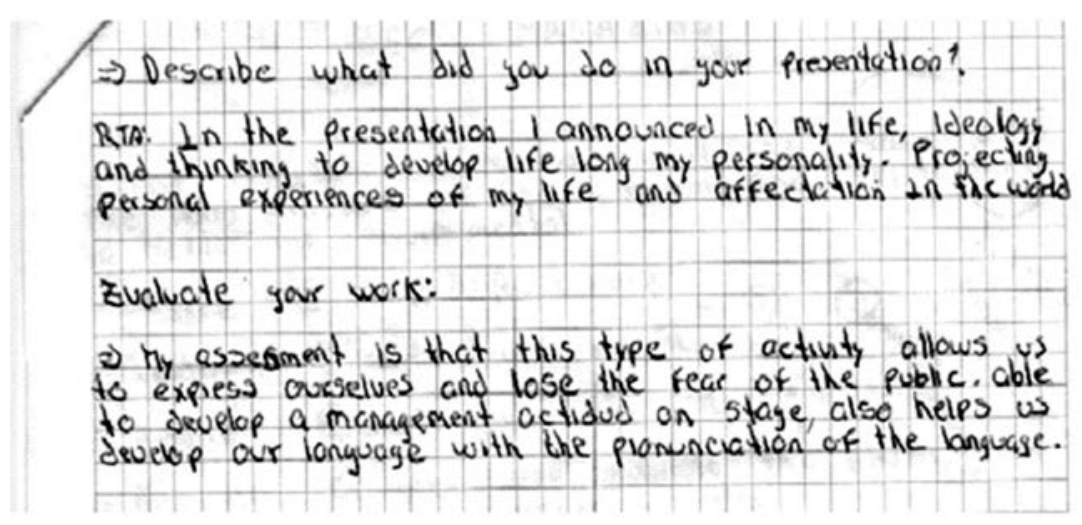

Figure 1. Sample from a Student's Self-Assessment

This social dimension helped them build their self-esteem, be responsible, distribute the workload, make better decisions, create involvement and a sense of belonging, and reinforce individual capabilities during the development of the magazine project.

Moreover, when students worked in groups, they strengthened their capacity to make decisions when learning. One of the most important decisions that learners made was to choose how they wanted to work; a resolution which facilitated the communication in each group (see Appendix 2). For example, S2 wrote that "the interaction was good; because of that we have a good communication" (SJ10). Indeed, the delegation of roles is a key point in effective cooperative work as is described in the following passage.

Each group assigned roles for making their magazines and accomplishing the tasks associated with this project. Students identified different roles they played such as editors and designers, according to their capabilities. "Some students decided to assign duties in each editorial group. For example, during the class they pointed the best writer in each team and the other duties" (SS8, FN8). In each group, there were students in charge of leading the magazine's process. For example, in the magazine called "Our Environment," students assigned the function of reader to another classmate "Hágale... usted sabe más que nosotros, sí...sì" 
[Do it...you know more than us, yes...yes] (S3, FN3). They were aware that each member of the group had different talents and took advantage of each student's abilities to get the best results on each task.

Sharing common interests is one of the main reasons for making decisions; students helped each other when necessary in their groups because they directed their efforts towards the magazine's production. It was evident that students decided to ask for help when they had doubts. Most of the groups had a collaborative climate where each member worked according to her/his own pace. For instance, S4 pointed out that he provided his partners with guidance: "the interaction with my group was fine but I had to help all the group near of my" [sic] while S11 was supported by his group: "The interaction with my group was good because of that my group help me" [sic].

Most of the groups had a collaborative climate where each member worked according to his/her own pace. For example, on the team of "Green People" magazine, S2 and S1 were characterized as having had a friendly relationship and both volunteered more time to work on their magazines in comparison with the other teams. They completed all tasks assigned to develop their magazine, but first, they liked to have fun for a few minutes before beginning their work (see Appendix 3) in which they were more conscious about their role in the group.

In conclusion, decision making encourages students to anticipate the consequences of their choices. In this case, they decided how to work in each group to produce their magazines. Tasks were structured to carry out individual and cooperative activities such as writing biographies and interviewing a person for which they had to exchange ideas, make plans, and propose solutions for solving problems. As a result, they decided to use learning strategies, defined as "the way in which the learner selects, acquires, organizes, or integrates new knowledge" (Weinstein \& Mayer, 1986, p. 315). This type of strategies contributed to their becoming more self-directed because students did not need to have the teacher around to guide them all the time. Learner autonomy did not imply that students learned alone or without their teachers since it required interaction with others in order to share what they had learned with the whole group. During cooperative work, learners explored their own likes, chose their own topics for writing, and organized how they were going to create and present their magazines. These types of tasks should be completed and integrated for the group's success.

\section{Self-Regulation}

Peña Dix (2013) highlighted that self-regulation was "the highest form of cognitive engagement" (p. 76), which was used by students to perform successfully in class. Students developed self-regulatory processes to find strategies to cope with their learning difficulties. Students' self-regulation was evident in the composition of each section of their magazines: 
the interview, the biography, the advertisement, the article, and the editorial in which they delegated duties (see Appendix 2).

For example, they acted as self-regulated learners, improved their communicative performance and successfully achieved the proposed tasks. Since they were aware of their learning process, they used different strategies to accomplish their duties in their groups. For instance, each group tried several versions of production to create their own magazines. While they were engaged in problem-solving, they not only asked for the teacher's support, but also used additional strategies. For example, they recognized their drawbacks and decided to use strategies for facing them such as asking classmates or the teacher, using dictionaries, and being more conscious of their learning (see Appendix 4). In fact, a learner tries to progress independently in a language classroom when there is a high degree of freedom for selecting topics, forming groups, organizing information, selecting feedback comments, and other functions. Students took a great degree of individual control over their compositions.

In this sense, a learner sustains an effort as long as he perceives the usefulness or instrumental value for doing so. Students decided to look for several strategies in order to overcome their weaknesses and be more self-determined to act individually. At this point, it is essential to highlight that students still made mistakes (see Appendices 4 and 5), but they did not interfere with the communication, a significant achievement taking into account that they were not able to express a single word in English at the beginning of the research project.

\section{Intrinsic Motivation}

In terms of enjoyment and satisfaction, intrinsic motivation refers to the "inherent tendency to seek out novelty and challenges, to extend and exercise one's capacities, to explore, and to learn" (Ryan \& Deci, 2000, p. 70). Intrinsic motivation is a key factor that allows learners to learn autonomously. Students displayed tendencies such as desire for knowledge and accomplishment during the implementation of this research project. Students were motivated to learn and were engaged in an activity for the satisfaction and inherent pleasure of the project. Indeed, the development of intrinsic motivation was evidenced when students expressed the desire to accomplish their goals and learn a foreign language, which are discussed in the next section. Desire for accomplishment came from the satisfaction that students experienced to complete their assignments: 75 percent of them expressed that they were always stimulated in learning English after the implementation of the project and 25 percent were almost always encouraged.

Students also expressed their feelings regarding presentations, in which they managed the appropriate subject + verb structure for building a basic sentence and although there are grammatical mistakes in some of them, the errors do not interfere with the understanding of 
those messages. For example, S8 graded his work as "very good because, I studied and explains of the best way that I could and I gave the best that I could" [sic]. In this case, this student expressed his natural inclination towards recognizing his work done in class. In addition to this, at the end of the study, students evaluated their own learning process and all of them were in agreement that they had become more independent and conscious to develop empowerment as well as responsibility to achieve goals (see Appendix 5).

The sense of pleasure and satisfaction felt after presenting their magazines was a visible sample of the encouragement that students felt during the implementation of this project. Another characteristic regarding intrinsic motivation is a desire for knowledge which was derived from the gratification that students felt when they carried out each activity. Students were able to communicate in English despite the common errors. There was a significant improvement in student composition in comparison with the writing portion of the diagnostic test, which most learners did not complete. However, grammatical mistakes can still be found in the writings as evident from student responses as in, for instance, students shared their most interesting biographies. When asked how he felt during the presentation, S6 said, "I was nervous but also was very sure than studied much" [sic] (Q2).

The creation of their own magazine was the main source of motivation for students. The desire for knowledge and accomplishment was the strongest feeling fostered by the students themselves. They were able to develop autonomy without the teacher's support. Reflection on the learning experience when evaluating this project helped students to become aware of the work they had done during the semester. The recognition of the underlined achievements presented made these learners more extrinsically and intrinsically motivated.

\section{Conclusions and Implications}

The purpose of this paper was to observe the role of project work on learner autonomy in an ESP class. This study showed that developing learner autonomy implies not only willingness to take control of learning, but also the necessity to provide students with opportunities to exercise autonomy by making decisions and assuming responsibility in groups for their own learning process. They also had the chance to work on teams to support each other and share preferences for fulfilling a common goal. This type of learning was observed through the implementation of this research study. The study suggests that projects can make students aware of their learning skills and allowed them to work on cooperative and individual tasks. In the magazine project, students developed learner autonomy different ways in relation to three aspects: (a) making decisions through cooperative work, (b) the development of self-regulation, and (c) intrinsic motivation.

The results of this study showed that most learners were aware of self-monitoring and self-evaluation strategies such as evaluating their progress and attempting to understand the 
reasons behind their mistakes. For instance, students did not have a high level of writing proficiency, so they decided to implement strategies such as working in teams, using dictionaries, reading, writing several peer-reviewed versions, listening to music in English, and watching TV. These strategies allowed students to overcome weaknesses in grammar and composition by helping them realize that they could find support in sources other than their teacher. In brief, students were self-motivated to improve their English by resorting to, or implementing facilitating learning strategies.

Students expressed intrinsic desires for knowledge and accomplishment and experienced a rewarding feeling as a result of the implementation of a project. Also, communication in English was one of the most important effects of this research project. Despite the fact that students still made mistakes and did not achieve the highest level of proficiency, they had concrete opportunities to put language into practice when doing the different sections of the magazines and sharing the work they had done over the course of the semester. The study provided additional evidence with respect to the effect of cooperative work to achieve common goals.

Cooperative work also had a positive influence on the increase of learners' autonomy to discuss and exercise more choices and control over their learning process. In each group, students assumed the responsibility for taking an active role in order to direct their learning responsibly to create their magazines together. They could also share with the entire class what they had learned to generate more ideas. Cooperative work fostered a high degree of autonomy because this type of work gives learners the freedom to explore their own preferences and to decide what activities are better for accomplishing their common goals.

In brief, learners can behave more autonomously when the teacher provides genuine learning opportunities in which students are actively engaged in the development of each activity proposed in the classroom. Students can interact and learn from their own mistakes whenever they are given meaningful choices and control of their learning. This kind of chance should be significant not only for teachers, but also for students. If learners are confident enough to control their own learning, they will choose beneficial ways to improve their own learning in the classroom.

Overall, the implementation of project work implies some changes in the language curriculum so that it goes beyond content and teacher-centeredness. Language teachers, then, need to reflect on how to define and design the course objectives, methodology, materials, tasks, and other aspects in order to foster learners' awareness, commitment, and command. Indeed, the development of learner autonomy does not only require the previous appropriate conditions, but also necessitates that students contribute on their own in order to become the active citizens our society requires. 


\section{References}

Beckett, G. H., \& Miller, P. C. (Eds.). (2006). Project-based second and foreign language education: Past, present, and future. USA: Information Age Publishing.

Corbin, J., \& Strauss, A. (1990). Grounded theory research: Procedures, canons, and evaluative criteria. Qualitative Sociology, 13(1), 3-21.

Duff, P. (2008). Case study research in applied linguistics. New York, NY: Taylor \& Francis Group.

Guo, Y. (2006). Project-based EFL in China. In G. H. Beckett \& P. C. Miller (Eds.), Project-based second and foreign language education: Past, present, and future (pp. 143-155). USA: Information Age Publishing.

Ho, R. (2003). Project approach: Teaching (2nd ed.). Hong Kong, HK: The Salvation Army Child Care Services. Retrieved from ERIC database. (ED478224)

Hyland, K. (2005). Stance and engagement: A model of interaction in academic discourse. Discourse Studies, 7(2), 173-192.

Jiménez Raya, M. (1994). Aprendizaje centrado en el alumno: Desarrollo de la autonomía del aprendiz de lenguas extranjeras [Student-centered learning: Development of foreign language learner's autonomy]. Didáctica del español como lengua extranjera, 8, 41-62.

Jiménez Raya, M., Lamb, T., \& Vieira, F. (2007). Pedagogy for autonomy in language education in Europe: Towards a framework for learner and teacher development. Dublin, IE: Authentik.

Legutke, M. K. (2005). Redesigning the foreign language classroom: A critical perspective on information technology and educational change. In C. Davison (Ed.), Information technology and innovation in language education (pp. 127-148). Hong Kong, HK: Hong Kong University Press.

Peña Dix, B. (2013). Motivation and the concept of self-regulation: Theory and implications for English language teaching and learning in Colombia. Voces y Silencios: Revista Latinoamericana de Educación, 4(1), 71-85.

Petersen, C. (2004). Project-based learning through the eyes of teachers and students: Investigating opinions of PBL in adult ESL (Master's thesis). University of Victoria, Canada.

Robayo Luna, A. M., \& Hernandez Ortiz, L. S. (2013). Collaborative writing to enhance academic writing development through project work. HOW, A Colombian Journal for Teachers of English, 20(1), 130-148.

Ryan, R. M., \& Deci, E. L. (2000). Self-determination theory and the facilitation of intrinsic motivation, social development, and well-being. American Psychologist, 55(1), 68-78.

Stoller, F. (1997). Project work: A means to promote language content. English Teaching Forum, 35(4), 2-9.

Stoller, F. (2002). Project work: A means to promote language content in methodology. In J. C. Richards \& W. A. Renandya (Eds.), Methodology in language teaching: An anthology of current practice (pp. 107-120). Cambridge, UK: Cambridge University Press.

Stoller, F. (2006). Establishing a theoretical foundation for project-based learning in second and foreign language contexts. In G. H. Beckett \& P. C. Miller (Eds.), Project-based second and foreign language education: Past, present, and future (pp. 19-40). USA: Information Age Publishing. 
Wallace, M. J. (1998). Action research for language teachers. Cambridge, UK: Cambridge University Press.

Weinstein, C. E., \& Mayer, R. E. (1986). The teaching of learning strategies. In M. C. Wittrock (Ed.), Handbook of research on teaching (3rd ed.) (pp. 315-327). New York, NY: Macmillan.

\section{The Author}

Martha Isabel Díaz Ramírez completed her master in Applied Linguistics for Teaching English as a Foreign Language at the University of Jaén (Spain). She has worked at Universidad La Gran Colombia and Universidad Antonio Nariño (Colombia) and she is currently working at Universidad de Cundinamarca (Colombia). 


\section{Appendix 1: Stages of Project Work (Adapted From Stoller, 2002)}

- A diagnostic test.

- Step 1: Agree on a theme for the project. Students chose "issues about environment."

- Step 2: Determine the final outcome. Students and teacher decided to develop a "magazine."

- Step 3: Structure the project. Students delegated functions. They defined the magazine's aims and characteristics.

- Step 4: Prepare the students for the language demands of Step 5.

- Topics explained by the teacher: how to express past events and experiences, future and present events, how to express obligation, advice, possibility, and duty with modals and how to write an article.

- Students' artifacts: questions in groups for interviews, biographies, advertisement, and articles.

\section{- Step 5: Gather information.}

- Students' drafts and corrections

- Teacher's feedback

- Step 6: Prepare the students for the language demands of Step 7.

- Brainstorming about writing an editorial

- Students' editorial drafts

- Teacher's feedback and student's correction

- Students organized and delegated functions for designing the magazine's layout.

- Step 7: Compile and analyze information.

- Students decided on magazine's layout and content.

- Teacher's feedback

- Step 8: Prepare the students for the language demands of Step 9.

- Teacher's suggestions

- Students' organization to complete presentations

\section{- Step 9: Present final product. Launching of their magazines.}

- Students' launching of their magazines

- Step 10: Evaluate the project.

- Self-assessment, peer assessment, and teacher's evaluation. 

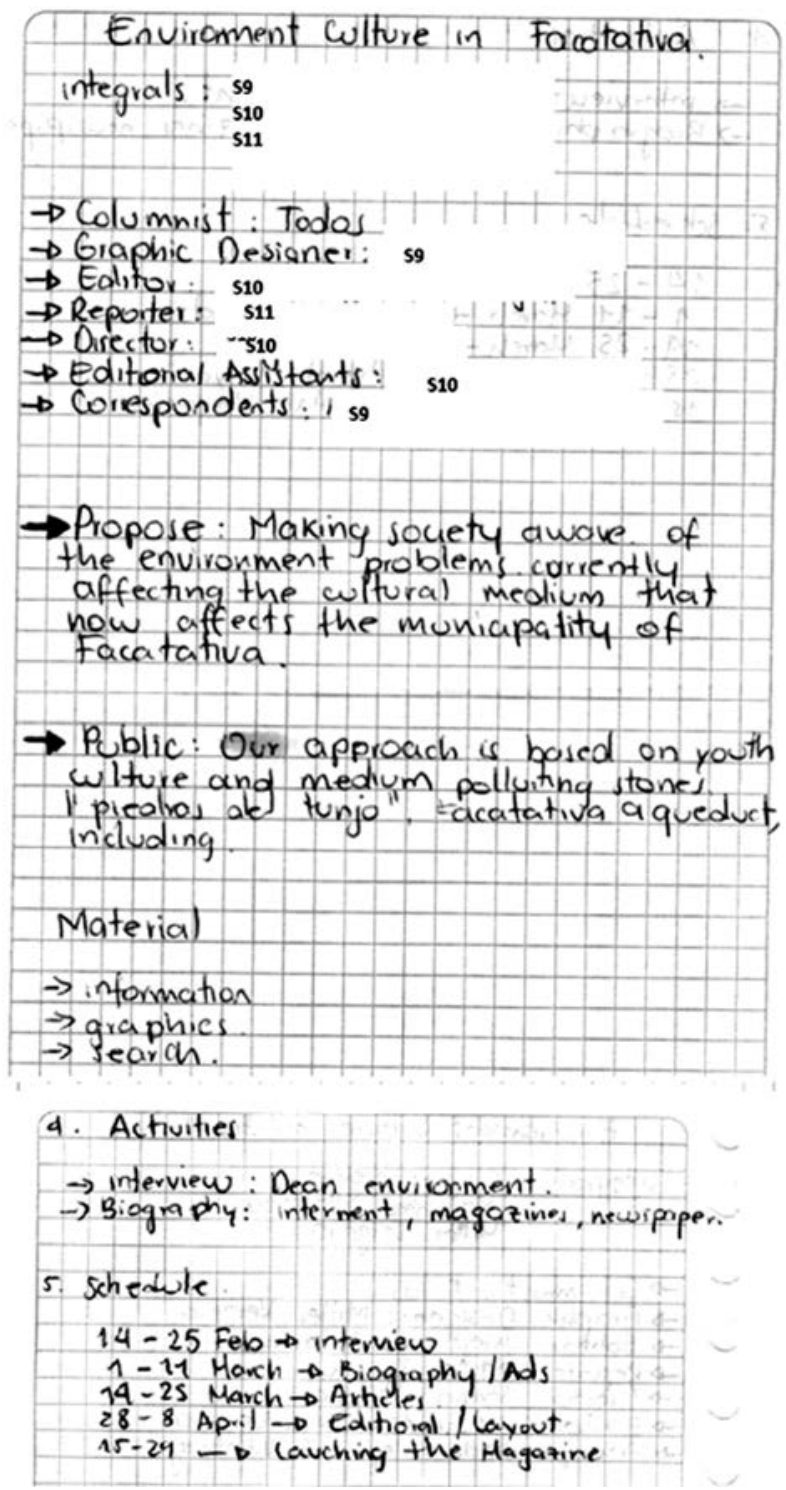


\section{Appendix 3: Field Notes Extracts}

Description (Preparation for writing the editorial and magazine's layout)

Some students decided to assign duties in each editorial group. For example, during the class, they pointed out the best writer for each team and the other duties:

1. Magazine "Green People":

At the beginning of the class, they were laughing and playing with cards. I called their attention because they were distracting their partners' attention and they said: "teacher usted sabe que [you know that] we work... (smiling) está bien, ya nos organizamos" [OK, we are going to prepare]. S14 was in charge of writing and S15 decided to organize the information and he preferred to work on the magazine's organization and layout.

2. Magazine "Our Environment":

Students chose S4 to write the editorial, S2 and S3 were in charge of organizing the information and taking photos, and S5 preferred to prepare the magazine's layout. 


\section{Appendix 4: Students' Drawbacks}

\begin{tabular}{|l|l|}
\hline \multicolumn{1}{|c|}{ Difficulties } & \multicolumn{1}{c|}{ Ss' Magazine journal } \\
\hline $\begin{array}{l}\text { I learn to realizate a magazine to a form } \\
\text { organize with all your elements and he also } \\
\text { added which difficulties were organize the } \\
\begin{array}{l}\text { word in the articles, the correction in My } \\
\text { biography and in the article [sic]. (S2) }\end{array}\end{array}$ & $\begin{array}{l}\text { I solve my difficulties with help of my } \\
\text { dictionary, the teacher, and my group [sic]. (S2) }\end{array}$ \\
\hline $\begin{array}{l}\text { My difficulties were the introduction and the } \\
\text { process to elaborate of magazine [sic]. (S1) }\end{array}$ & $\begin{array}{l}\text { I question to my classroom....and to the } \\
\text { teacher and dictionary [sic]. (S1) }\end{array}$ \\
\hline
\end{tabular}




\section{Appendix 5: Project's Assessment}

\section{Are you more autonomous? Explain}

S1: Yes I am now more independent and therefore do not seek the help of others before and normally use different types of help to develop a project, I use internet or books [sic].

S2: Yes, because during the course of the semester...I was improving writing and pronunciation $[$ sic $]$.

S3: Yes, with the development of this project I was able to put my difficulties to make them strengths $[s i c]$.

S4: Yes, in the English class learn most, for this reason I am more autonomous, for write and for speak English [sic].

S5: Yes I am more autonome for the study in the class, this very good option for a best apprentice $[$ sic] .

S6: Yes straightforward to write paragraphs [sic].

S7: Yes more autonomous because search in internet and book the theme of English [sic].

S8: Yes because I do my work as I believe apropriate and more understandable for my [sic].

S9: Yes because I lear more and now undersdand major the English [sic].

S10: Yes I more autonomous because now I'm most responsible for the English lesson [sic].

S11: Yes, because I have more vocabulary and writing [sic].

S12: Yes, because of that now I can did more writers and can talk more in English [sic].

S13: I think so yes because I knowed some of this class [sic].

S14: Yes now I am an person more autonomie for learning to get in class room [sic].

S15: Yes I do my work [sic].

S16: 50/50 because I need learn more [sic]. 